\title{
Estudo da Rigidez do Ligamento Cruzado Anterior do J oelho e dos Enxertos para sua Reconstrução com o Ligamento Patelar e com os Tendões dos Músculos Semitendíneo e Grácil
}

\author{
Rigidity of the Knee Anterior Cruciate Ligament and Grafts to Reconstruct It with the Patellar \\ Ligament and with the Semitendinosus and Gracilis Muscles
}

Carlos Górios; Arnaldo J osé Hernandez, Marco Martins Amatuzzi, Tomaz Puga leivas, César Augusto Martins Pereira, Raul Bölliger Neto, Edgard dos Santos Pereira

\section{RESUMO}

Com o objetivo de avaliar a rigidez do ligamento cruzado anterior dos enxertos preparados para sua reconstrução a partir da porção central do ligamento patelar e dos tendões dos músculos semitendíneo e grácil duplos, oriundos dos mesmos joelhos, 0 autor utiliza 20 joelhos de cadáveres humanos, frescos, todos masculinos, com idade média de 32,2 \pm 8,9 anos, variando de 17 a 47 anos. As estruturas analisadas foram submetidas a três ensaios mecânicos de tração, com intervalos de 10 minutos para recuperação, em máquina Kratos K-5002 (eletromecânica), com velocidade de $20 \mathrm{~mm} / \mathrm{min}$ até atingir 147,15 N (15 kgf), mantendo-as alongadas por um período de 15 minutos. Todas as estruturas observadas apresentam um aumento da rigidez aos sucessivos testes realizados, exceto entre $02^{\circ}$ e $03^{\circ}$ teste do ligamento cruzado anterior onde não apresentou diferença estatística. A análise estatística permite concluir que os ciclos sucessivos dos ensaios mecânicos determinam um aumento da rigidez dos enxertos analisados.

Descritores: J oelho. Enxertos. Rigidez

\section{SUMMARY}

The aim of this study was to evaluate the stiffness of the anterior cruciate ligament and of the grafts prepared for its reconstruction from the central portion of the patellar ligament and of double semitendinosus and gracilis tendons originated from the same knees. The author utilizes 20 knees of fresh human cadavers, all male, with average age of $32,2 \pm 8,9$ years, ranging from 17 to 47 years. The structures analyzed were submitted to three mechanical traction tests, with 10 minutes intervals for recovery in a Kratos K-5002 (electromechanical) machine, with $20 \mathrm{~mm} / \mathrm{min}$ speed up to $147,15 \mathrm{~N}$ (15 kgf) and then keeping them stretched for a 15 minutes period tests. All structures tested show increase of stiffness, unless between $2^{\circ}$ and $3^{\circ}$ test to anterior cruciate ligament didn't have statistical difference. The statistical analysis, provided the following conclusions that repeated cycles of mechanic al test determine an increase in the stiffness of the grafts analyzed.

Key words: Knee. Grafts. Stiffness. 


\section{INTR ODUÇÃO}

A reconstrução do ligamento cruzado anterior (LCA) do joelho é um dos procedimentos ortopédicos que mais tem recebido atenção nos últimos anos, levando a um aprimoramento das técnicas utilizadas. Entretanto, ainda não se encontrou a solução ideal para a instabilidade causada pela insuficiência desse ligamento.

A meta principal da reconstrução ligamentar do joelho é a restauração da sua estabilidade fisiológica e da sua função normal. A utilização da porção central do ligamento patelar (LP) na reconstrução do ligamento cruzado anterior tem sido utilizada por muitos cirurgiões ortopédicos. ${ }^{(1,8,14)} \mathrm{Com}$ o desenvolvimento das técnicas de fixação, os tendões dos músculos semitendíneo e grácil (STG) voltaram a ser utilizados para esse fim. ${ }^{(9,15)}$

Vários investigadores estudam as propriedades biomecânicas dos ligamentos do joelho e dos substitutos utilizados nas suas reconstruções. Entretanto, devido à maior complexidade técnica, os estudos específicos para a determinação das propriedades viscoelásticas, necessárias para melhor compreensão do comportamento dinâmico das articulações e de seus estabilizadores, não tem recebido a necessária atenção por parte desses mesmos autores.

A determinação dessas propriedades é fundamental para a melhor seleção dos enxertos e para o desenvolvimento das técnicas de fixação. A variação da rigidez interferem diretamente na estabilidade articular e podem determinar o sucesso, ou fracasso, de uma reconstrução ligamentar.

Dentre os erros da técnica cirúrgica, o tensionamento impróprio do enxerto pode levar ao insucesso da reconstrução. YOSHIYA et al., em 1987, afirmam que o excesso de tensão aplicada ao enxerto, leva a uma redução na vascularização e à degeneração mixóide. Portanto, uma tensão inadequada, poderá determinar a recorrência da instabilidade ligamentar do joelho.

Diversos autores tem dado ênfase à tensão aplicada no enxerto previamente a sua fixação, no momento da reconstrução, o que tem sido denominado de pré-tensionamento $(3,20)$

A importância do pré-tensionamento pode ser avaliada através do estudo de algumas propriedades mecânicas. 0 objetivo deste trabalho é analisar, experimentalmente num mesmo joelho, a rigidez do ligamento cruzado anterior e dos enxertos utilizados para sua reconstrução com o ligamento patelar e com os tendões dos músculos semitendíneo e grácil.

\section{INTRODUCTION}

In recent years, reconstruction of the anterior cruciate ligament ( $A C L)$ of the knee is one of the most focused orthopedic procedures accounting for a refinement of the techniques in use. However, the ideal solution for the instability caused by insufficiency in this ligament has not been found.

The main objective in knee ligament reconstruction is to restore its physiologic al stability and normal function. The central part of the patellar ligament $(P L)$ has been used by a number of orthopedic surgeons to reconstruct the anterior cruciate ligament. ${ }^{1,8,14}$ With the development of fixation techniques, the semitendinosus and gracilis muscles (STG) tendons are used anew. ${ }^{9,15}$

Several investigators studied the biomechanical properties of the knee ligaments and their substitutes employed in the reconstructions. However, due to higher technical complexity, studies specific to determine the viscoelastic properties to better understand the dynamic behavior of the joints and their stabilizers have not received the necessary attention on the part of these authors.

Determination of these properties is fundamental to better select grafts and to develop fixation techniques. Variation in rigidity directly interferes with the articular stability and can determine success or failure of a ligament reconstruction.

Among the errors which can be observed in the surgical technique, inadequate tensioning of the graft can result in unsuccessful reconstruction. YOSHIYA et al., in 1987, stated that excessive tension applied on the graft causes reduction in vascularization and mixoid degeneration. Consequently, inadequate tension can determine recurrence of ligament instability in the knee.

Several authors emphasized the tension applied to the graft previously to its fixation, in the moment of reconstruction, and this has been called pre-tensioning ${ }^{3,20}$

The importance of pre-tensioning can be evaluated studying some mechanical properties. The objective of this study is to experimentally analyze, in the same knee, the rigidity of the anterior cruciate ligament and of the grafts used in its reconstruction with the patellar ligament and with the semitendinosus and gracilis muscles tendons. 


\section{MATERIAL E MÉTODOS}

Foram estudados 20 joelhos de 12 cadáveres humanos frescos, com idade média de $32,2 \pm 8,9$ anos variando de 17 a 47 anos, sendo $10(50 \%)$ do lado direito e todos do sexo masculino. Não foram incluídos espécimes que apresentassem indícios de ocorrência de doenças consuptivas prévias ou alterações do joelho como deformidades, cicatrizes cirúrgicas ou evidências clínicas de lesões prévias.

Nos joelhos dos cadáveres foram realizadas osteotomias do fêmur e da tíbia, com serra manual, a 15 centímetros da superfície articular, preservando-se os tendões dos músculos isquiotibiais, ligamento patelar com a patela e todos os demais ligamentos do joelho.

Retirou-se, de cada peça anatômica, a porção média do ligamento patelar, de largura aproximada de um centímetro, e com blocos ósseos da patela e da tuberosidade anterior da tíbia de mesma largura, aproximadamente três centímetros de comprimento e um centímetro de profundidade, utilizando-se osteótomo e martelo.

Retiraram-se os tendões dos músculos semitendíneo e grácil, através de dissecção anatômica junto a inserção dos mesmos. Após retirar-se a porção muscular e outros resíduos de tecidos, esses tendões eram isolados e seccionados com dimensão padronizada de 14 centímetros de comprimento. Essa dimensão permite dobrá-los ao meio com obtenção de dois tendões duplos (semitendíneo e grácil) com sete centímetros de comprimento cada um.

Realizou-se, finalmente, a retirada dos músculos, ligamentos, cápsula articular e demais tecidos moles ao redor do joelho, preservando-se somente $o$ ligamento cruzado anterior. 0 terço proximal da fíbula também foi retirado.

\section{Fixação dos Corpos de Prova}

O segmento ósseo do fêmur foi fixado em garra metálica tubular dotada de parafusos radiais com ponta cônica para fixação na cortical óssea, especialmente desenvolvida para esse fim. 0 terço proximal da tíbia foi também fixado numa

segunda garra tubular metálica, com extensão em "L", de maneira análoga à fixação do fêmur (figura 1).

O enxerto preparado com o LP foi fixado proximal e distalmente, através da colocação dos fragmentos ósseos, em garras compostas por duas placas metálicas, retangulares,

\section{MATERIALS AND METHODS}

Twenty (ten right and ten left) knees from 12 fresh 17-47 yearold male corpses, mean aged $32.2 \pm 8.9$ years were studied. Specimens showing evidence of previous consumptive diseases, knees with alterations such as surgical scars or clinical evidence of previous lesions were not included in this study.

Using a manual saw, femoral and tibial osteotomies were carried out in the knees, $15 \mathrm{~cm}$ from the articular surface, presenving the ischiotibial muscles tendons, the patellar ligament with the patella, and all other knee ligaments.

Using ostheotome and hammer app roximately one centimeter wide middle portion of the patellar ligament, with patellar and tibial anterior tuberosity bone blocks of the same width and about three centimeters long and one centimeter deep was removed from each sample.

The semitendinosus and gracilis muscles tendons were withdrawn adjacent to their insertion through anatomical dissection. After removing the muscular tissue and other debris, the tendons were isolated and sectioned in $14 \mathrm{~cm}$ long pieces. This length allows to fold them in the middle producing two $7 \mathrm{~cm}$ long double tendons (semitendinosus and gracilis).

Removal of muscles, ligaments, articular capsules and soft tissues around the knee was effected preserving only the anterior cruciate ligament. The proximal third of the fibula was also removed.

\section{Fixation of the Samples}

The femoral bone segment was fixed in the bone cortical using specially designed tubular metal clamps with radial screws provided with conical tips. The tibia proximal third was similarly fixed in tubular metal clamps with extension in "L" (Figure 1).

The grafts prepared with the PL were proximally and distally fixed placing the bone fragments in clamps made up by two rectangular metal plates with an internally sinusoid notched profile and intermediate devices in one end to allow their assembly in the machine test (Figure 2). 
dotadas de perfil denteado sinusoidal em sua face interna e com dispositivos intermediários, em uma das extremidades, que permitem sua montagem na máquina onde serão realizados os ensaios (figura 2).

O enxerto preparado com tendões STG foram dobrados sobre si mesmos, adquirindo uma conformação quádrupla e fixado no lado correspondente às extremidades livres dos tendões em garra descrita anteriormente para o LP. A extremidade correspondente à dobra dos tendões foi fixada a cavaleiro em pino cilíndrico polido de aço, com meio centímetro de diâmetro. Padronizou-se em três e meio centímetros 0 comprimento dos tendões fixados na garra, deixando-se o restante do enxerto livre para os ensaios mecânicos (figura 3).
The grafts prepared with the STG tendons were folded as to acquire quadruple conformation and were fixed on the side correspondent to the tendons free ends in the clamps described

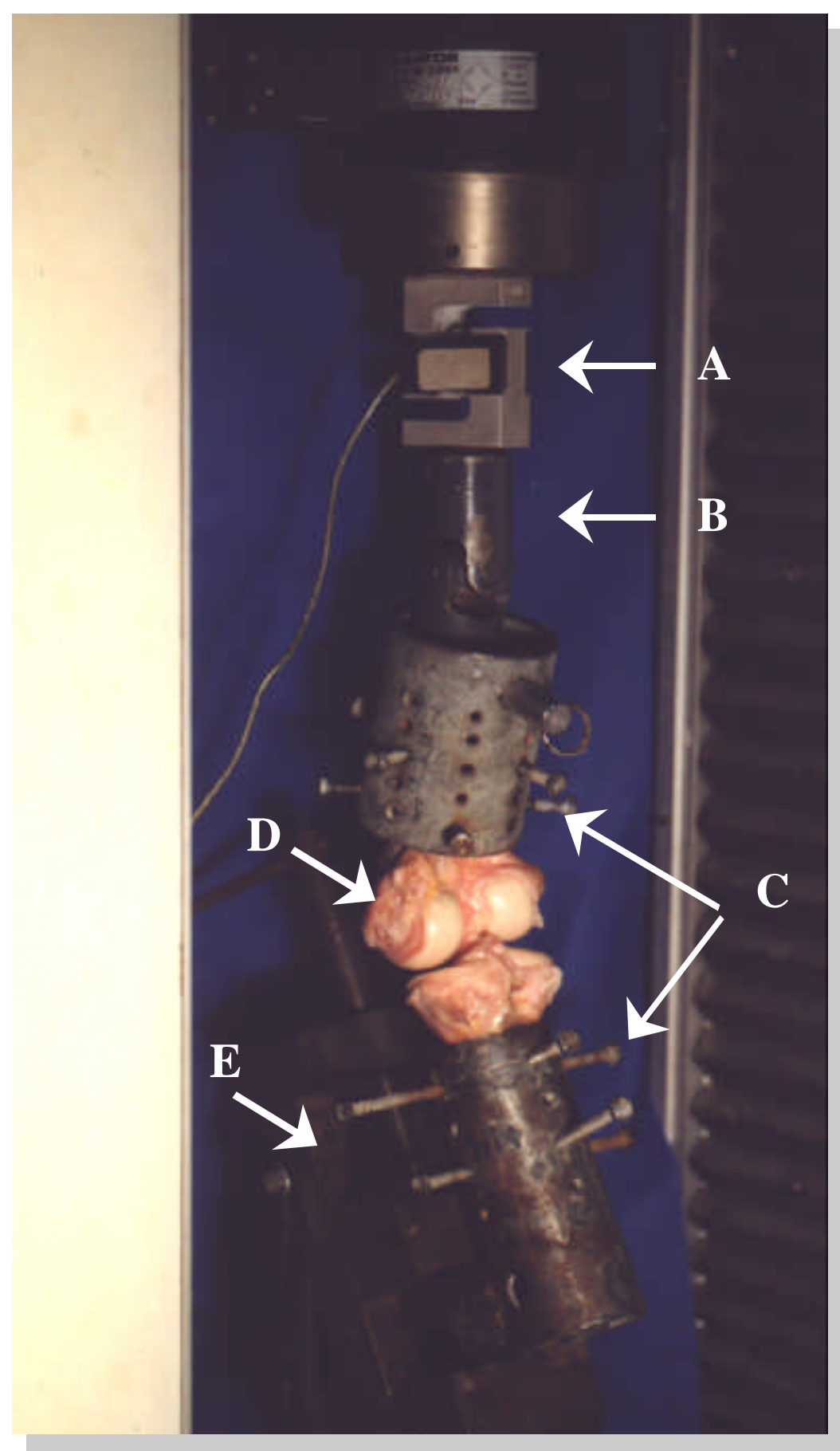
above. The extremities which corresponded to the folding of the tendons were fixed astride in a cylindrical 0.56 $\mathrm{cm}$ diameter polished steel pin. Three and a half centimeters was the tendons standard length fixed in the clamps; the remaining part was left free for the mechanical tests (Fig. 3).

\section{Figura 1}

Ensaio de relaxamento à tensão do ligamento cruzado anterior:

A - célula de carga eletrônica $\mathrm{CCl}$ de 100 kgf;

B - junta universal;

C - garras tubulares com parafusos radiais para fixação diafisária;

D - joelho com ligamento cruzado anterior íntegro;

E - torno de fixação com inclinação ajustada à 30 e e centralização deslizante.

\section{Figure 1}

Tension relaxation test of the anterior cruciate ligament.

A - $100 \mathrm{kgf} \mathrm{CCl}$ electronic al load cell;

$B$ - universal assembly;

C - tubular clamps with radial screws to fix the diaphysis;

D - knee with intact anterior cruciate ligament; and

E - fixation lathe with a $30^{\circ}$ inclination and sliding centralization. 


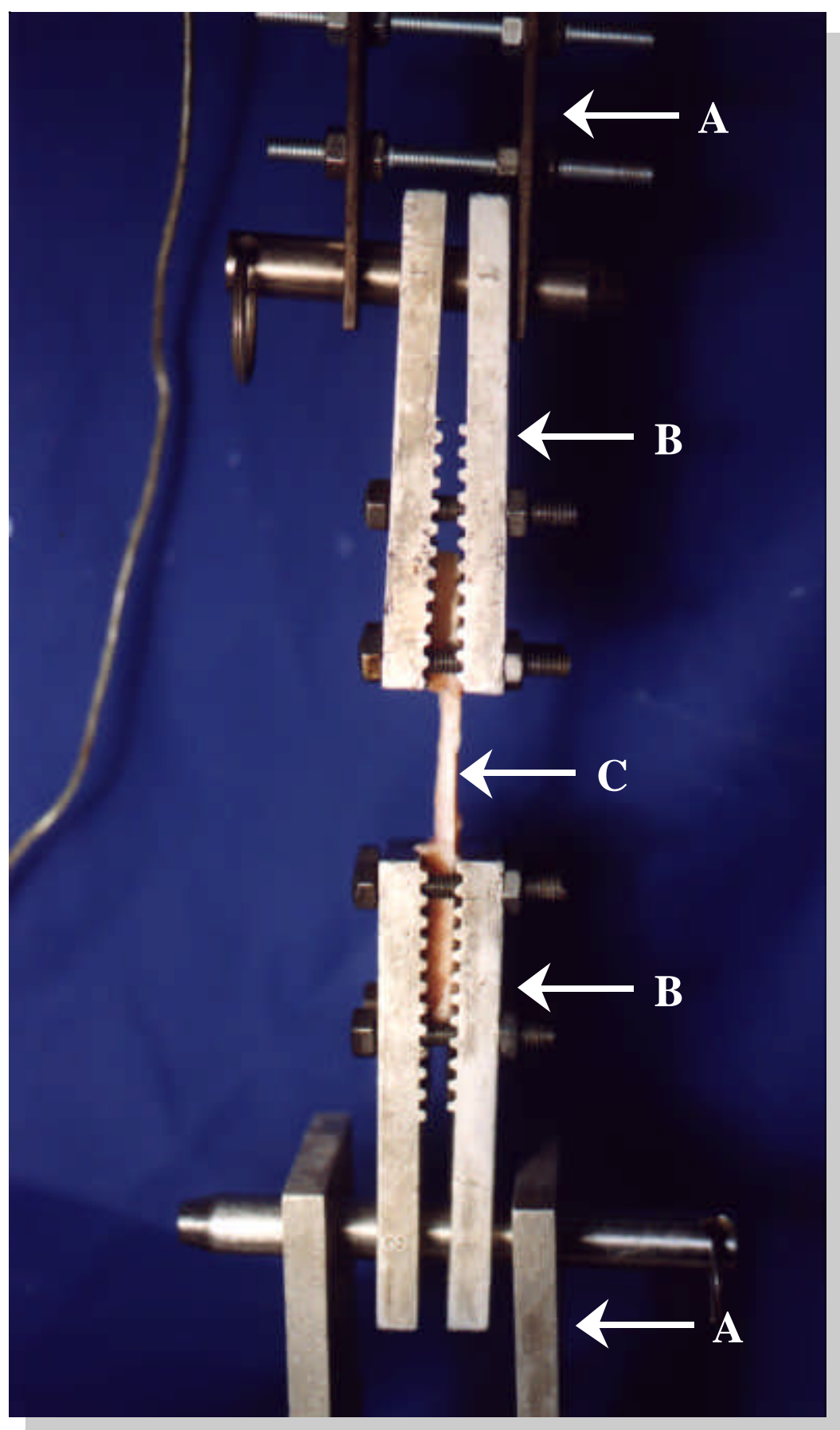

\section{Figura 2}

Ensaio de relaxamento à tensão do enxerto preparado com a porção central de ligamento patelar:

A - dispositivos intermediários;

B - garras sinusoidais para fixação dos blocos ósseos;

C - porção central do ligamento patelar.
Figure 2

Tension relaxation test of a graft prepared with the patellar ligament central part.

A - intermediate devices:

B - sinusoidal clamps to fix the bone blocks;

C - central part of the patellar ligament. 


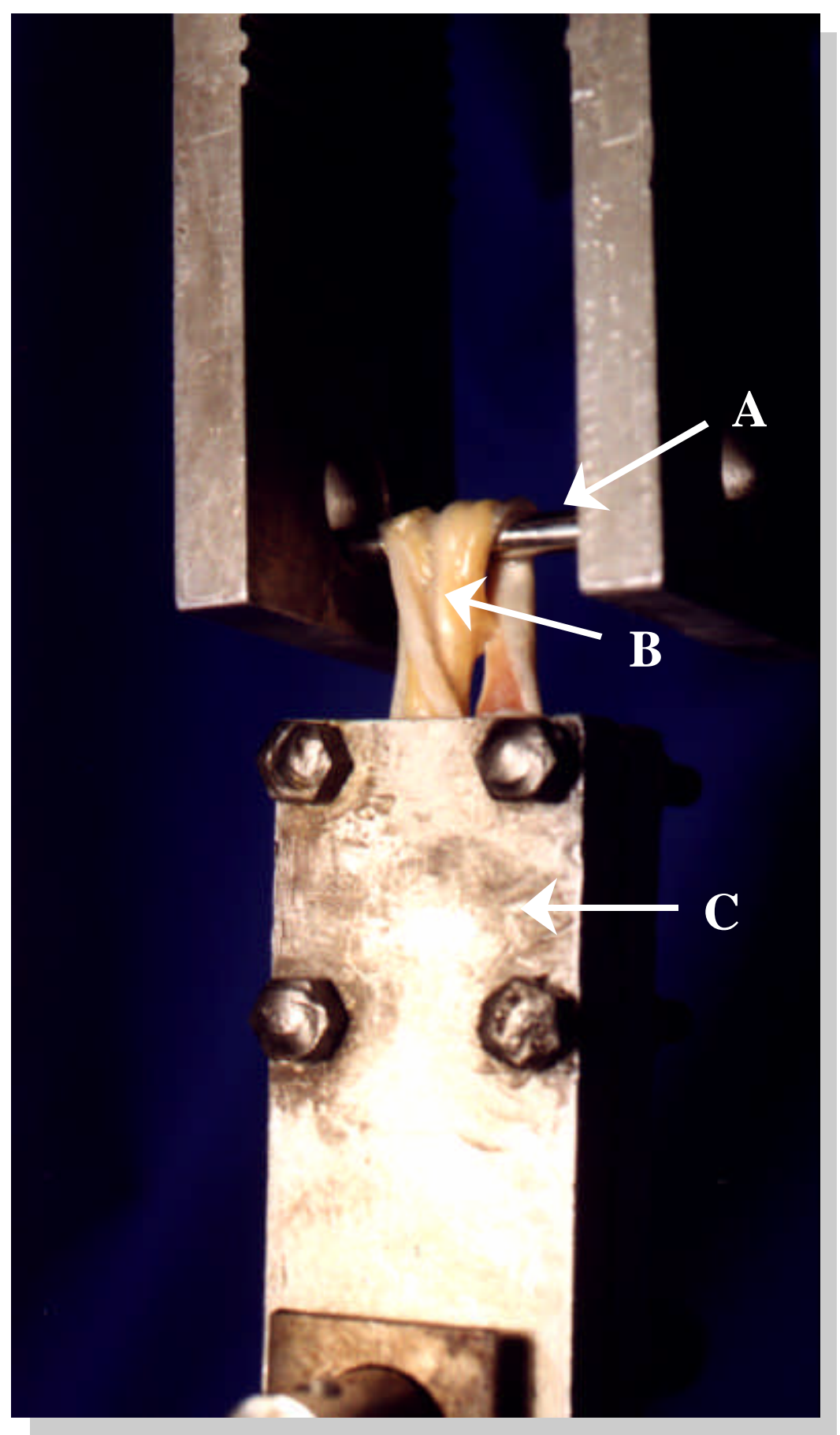

\section{Figura 3}

Ensaio de relaxamento à tensão do enxerto preparado com os tendões, dos músculos semitendíneo e grácil, duplos, dobrados sobre si mesmos:

A - pino de fixação, com rotação livre para fixação da extremidade do enxerto, à cavaleiro;

B - enxerto dos tendões, duplos, dos músculos semitendíneo e grácil;

C - garra sinusoidal em alumínio para fixação das extremidades livres dos tendões.
Figure 3

Tension relaxation test of graft prepared with double, folded semitendinosus and gracilis muscles tendons.

A - fixation pin, with free rotation to fix the graft end, astride; B - graft of double tendons of the semitendinosus and gracilis muscles;

C - sinusoidal clamps in aluminium to fix the tendon free extremity. 
Ensaios Mecânicos

Realizou-se os ensaios, em máquina universal de ensaios mecânicos eletromecânica Kratos ${ }^{\circledR} \mathrm{K} 5002$ dotada de célula de carga eletrônica $\mathrm{CCl}$ de 100 kgf. A precisão do sistema para a medida da carga foi de $10 \mathrm{~g}$. A máquina operou monitorada por um microcomputador IBM PC ${ }^{\circledR}$ compatível que adquiriu e tratou os dados de todos os ensaios.

Cada corpo de prova foi submetido a três ensaios de relaxamento à tensão sucessivos. Nesses ensaios, realizou-se inicialmente a uma tração uniaxial livre, quase-estática, sob uma taxa de deformação de $20 \mathrm{~mm} / \mathrm{min}$ até atingir a resistência nominal de $147,15 \mathrm{~N}$ (15kgf) quando ocorria uma parada automática pré- programada. Essa força foi denominada força de pico $\left(F_{p}\right)$.

A deformação foi mantida durante 15 minutos. Em seguida, retirou-se a carga lentamente até atingir uma carga nula estável. Neste instante registrou-se a deformação residual.

Entre os testes sucessivos de um mesmo corpo de prova (ciclos) estabeleceu-se um período de 10 minutos para recuperação.

Foi gerado diagrama convencional de força $(\mathbf{N}) \times$ deformação (mm).

\section{Diagrama Força x Deformação}

Utilizou-se o diagrama força $(\mathrm{N}) \mathrm{x}$ deformação $(\mathrm{mm})$ (figura 4) para determinação da constante de proporcionalidade ou rigidez $(k)$, que avalia a proporção entre a carga aplicada e a deformação obtida em fase elástica. A rigidez $(\mathrm{k})$ corresponde a tgfisß, onde é $ß$ o ângulo da inclinação do diagrama força $x$ deformação na fase linear ascendente até o ponto que foi definido como força de pico $\left(F_{p}\right)$, ou tração máxima inicial, e estabelecida de forma nominal, conforme já apresentado, em 147,5 N. Analisou-se a variação da rigidez de cada corpo de prova nos sucessivos testes realizados e comparou-se a rigidez das diferentes estruturas. Analisou-se a variação da rigidez de cada corpo nos sucessivos testes realizados e comparou-se a rigidez das diferentes estruturas.
Mechanic al Tests

A universal $\mathrm{Kratos}^{\circledR} \mathrm{K} 5002$ electromechanical machine test with a $100 \mathrm{kgf} \mathrm{CCl}$ electronic load cell was used. Accuracy of the load measuring test was $10 \mathrm{~g}$. The machine was monitored by a compatible IBM PC ${ }^{\circledR}$ computer which retrieved and analyzed the data.

Each sample was submitted to three successive tension relaxation tests. In these tests, a free uniaxial quasi-static traction was initially exerted, under a $20 \mathrm{~mm} / \mathrm{min}$ deformation rate until a $147.15 \mathrm{~N}$ (15 kgf) nominal resistance when a pre-programmed automatic stop occurred. This force was named peak force $\left(F_{p}\right)$.

Deformation was maintained for 15 minutes. After that, the load was slowly reduced until a stable null load and the residual deformation was then registered.

Among the successive tests of each sample (cycles) a 10 minute recovery period was established.

A conventional force $(\mathrm{N}) \mathrm{x}$ deformation $(\mathrm{mm})$ diagram was developed.

\section{Force x Deformation Diagram}

A force $(\mathrm{N}) \times$ deformation ( $\mathrm{mm}$ ) diagram (Figure 4) was used to determine the proportionality or rigidity constant $(k)$, which evaluates the proportion between the applied load and the deformation obtained in the elastic phase. Rigidity (I) corresponds to $\operatorname{tg}_{\text {ilegive }} p ; b$ is the inclination angle of the force $x$ deformation diagram in the ascendant linear phase until the point defined as peak force $\left(F_{p}\right)$ or maximum initial traction, and nominally established as $147.5 \mathrm{~N}$. Each sample variation in rigidity was analyzed in the successive tests, and rigidity of the different structures was compared. 


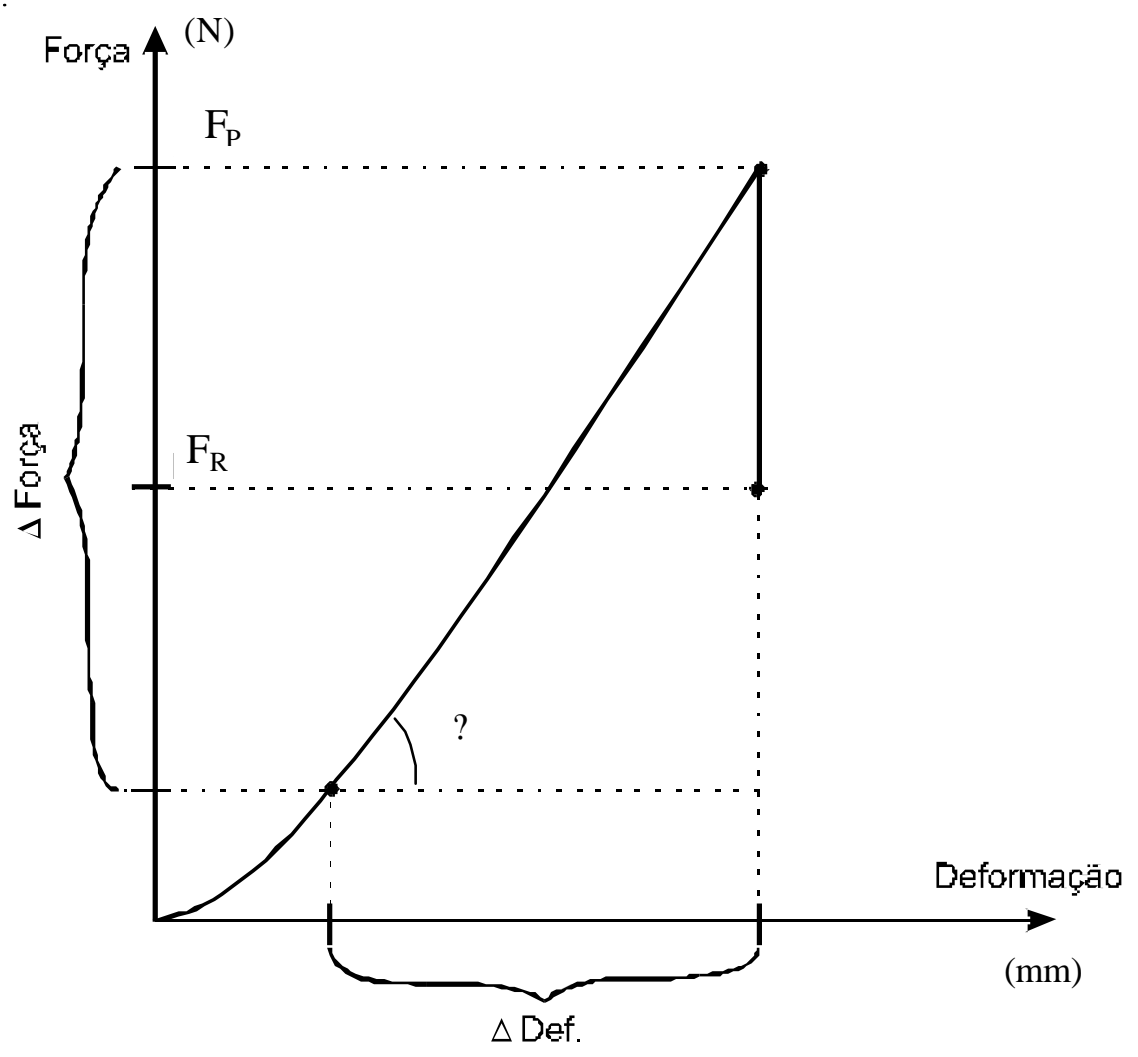

\section{Figura 4}

Diagrama convencional força $(\mathbf{N})$ - deformação $(\mathrm{mm})$ do ensaio de relaxamento à tensão utilizado para determinação da constante de proporcionalidade (índice de rigidez) em regime elástico (fase linear ascendente do diagrama).

$\mathbf{F}_{\mathbf{P}}=$ Força de pico $(\mathbf{N})$ ou força de tração máxima inicial. Valor nominal $=147,15 \mathrm{~N}(15 \mathrm{kgf})$

$\mathbf{F}_{\mathbf{R}}=$ Força após $900 \mathrm{~s}$ (15 min) de relaxamento $(\mathbf{N})$

$\mathbf{k}=$ Constante de proporcionalidade (rigidez) $=\operatorname{tg}_{\text {fis }} a=D$ força I $D$ deformação, determinada em regime elástico ou na fase linear ascendente da curva

? = Ângulo de inclinação da fase linear do diagrama

\section{Figure 4}

Conventional diagram $(\mathbf{N})$ - deformation $(\mathrm{mm})$ of the tension relaxation test used to determine the proportionality constant (rigidity index) in the elastic regimen (ascendant linear phase).

$\mathbf{F}_{\mathbf{p}}=$ Peak force $(\mathbf{N})$ or initial maximum traction force. Nominal value $=147.15 \mathbf{N}(15 \mathrm{kgf})$

$\mathbf{F}_{\mathbf{R}}=$ Force after $900 \mathrm{~s}(15 \mathrm{~min})$ of relaxation $(\mathbf{N})$.

$\mathbf{k}=$ Proportionality constant (rigidity) $=\operatorname{tg}_{\text {fis }} \quad a=D$ force $/ D$ deformation, determined in elastic regimen or in the ascendant linear phase of the curve.

? ?= Inclination angle of the diagram linear phase. 


\section{Análise Estatística}

Para os parâmetros ordinais (quantitativos) foram calculadas: a média (M), desvio padrão (DP), erro padrão da media (EPM), valor máximo(MAX), valor mínimo (MIN) e número de casos (N).

Compara-se o parâmetro rigidez ( $k$ ) entre o $1^{\circ}$, 20 e 30 ciclos de cada estrutura estudada através dos testes de Análise de Variância (ANOVA) para as amostras com comportamento paramétrico e Friedman para as amostras não paramétricas. Nos casos significativos as diferenças individuais foram discriminadas pelo teste de Tukey para a ANOVA e pelo teste de comparações múltiplas modificado po Dunn para o de Friedman.

Os parâmetros citados acima, também foram comparados entre as estruturas estudadas dois a dois LCA-LP, LCA-STG e LP-STG utilizando-se os testes t pareado, para as amostras paramétricas, e Wilcoxon para amostras não paramétricas.

Desprezaram-se os dados de dois diagramas referentes ao 3 ciclo do ligamento cruzado anterior resultando amostras com 18 casos $(\mathrm{N}=18)$, devido a problemas técnicos durante os ensaios.

Na tabela 2, os índices subscritos, 1,2 ou 3, referem-se respectivamente à 10,20 ou 3 을 ciclo, e os índices 1-2,2-3 e 1-2-3 indicam a utilização dos valores médios entre os ciclos indicados, nos casos onde não se demonstram diferenças entre elas.

Adotou-se o nível de significância de $5 \%\left(a_{.}=0,05\right)$. Os resultados significativos foram evidenciados por asteriscos $(*)$.

\section{RESULTADOS}

Os resultados dos ensaios mecânicos realizados encontramse nas tabelas 1 e 2. São apresentados os valores da estatística descritiva, média (M), desvio padrão (DP), erro padrão da média (EPM), valores mínimo (MIN) e máximo (MAX) e número de casos (N), para o ligamento cruzado anterior (LCA), o enxerto preparado com a porção central do ligamento patelar (LP) e para o enxerto preparado com os tendões, duplos, dos músculos semitendíneo e grácil (STG) e os resultados dos testes estatísticos.
Statistical Analysis

Mean (M), standard deviation (SD), mean standard error (MSE), maximum value (MAX), minimum value (MIN) and number of cases (N) were calculated for the ordinal (quantitative) parameters.

The parameter rigidity $(\mathrm{k})$ was compared in the $1^{\text {st }}, 2^{\text {nd }}$, and $3^{\text {rd }}$ cycles of each structure using the Variance Analysis (ANOVA) for samples with parametric behavior and Friedman for nonparametric samples. In the significant cases, the individual differences were discriminated by the Tukey test for ANOVA, and by the multiple comparisons test modified by Dunn for Friedman.

The above mentioned parameters were also compared conceming structures studied in pairs, ACL-PL, ACL-STG and PL-STG, using the t-paired tests for the parametric samples and Wilcoxon for the non-parametric samples.

Data from two diagrams referring to the $3^{\text {rd }}$ cycle of the anterior cruciate ligament were discarded due to technical problems, resulting in samples from 18 cases $(N=18)$.

In Table 2, the indices with subscripts 1, 2 or 3 refer respectively to the $1^{\text {st }}, 2^{\text {nd }}$ or $3^{\text {rd }}$ cycles, and the indices $1-2,2-3$ and $1-2-3$ indicate the utilization of mean values in the these cycles in the cases where differences are not evidenced.

The $5 \%$ significance level was adopted $(a=0.05)$. The signific ant results are evidenced by asterisks $(*)$.

\section{RESULTS}

Tables 1 and 2 depict the results of the mechanical tests: descriptive statistical figures, mean (M), standard deviation (SD), mean standard error (MSE), minimum (MIN) and maximum (MAX) values, and number of cases $(\mathrm{N})$, for the anterior cruciate ligament $(A C L)$, for the graft prepared with the central part of the patellar ligament (PL), for the graft prepared with double tendons of the semitendinosus and gracilis muscles (STG), and the statistical tests results. 
Comparação do índice de rigidez, em N/mm, entre as estruturas estudadas nos três ensaios realizados.
The rigidity index in $\mathrm{N} / \mathrm{mm}$ of the structures studied in the three experiments was compared.

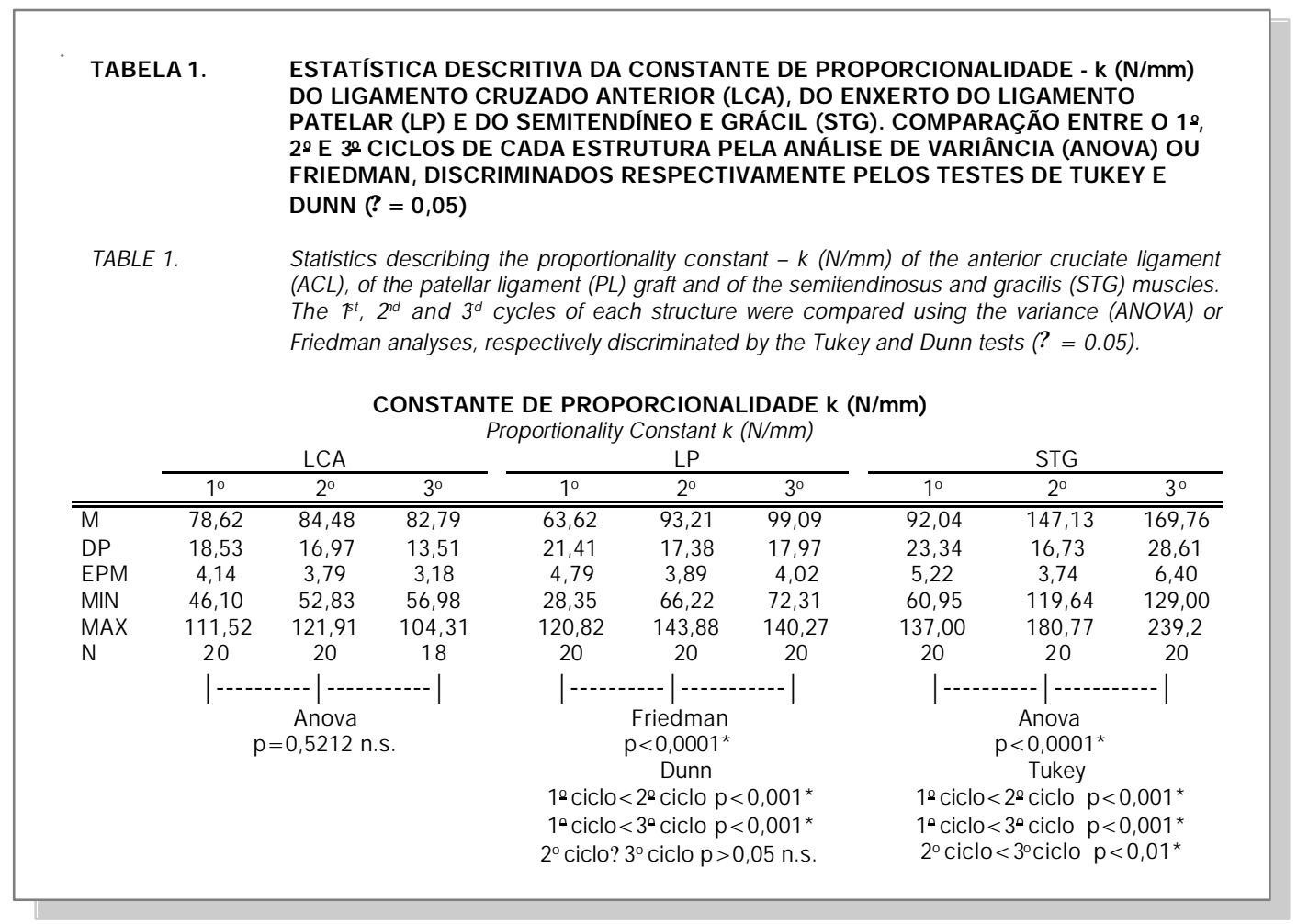

$\mathrm{Na}$ Tabela 2 realizamos a comparação entre as estruturas com relação ao índice de rigidez.
Table 2 presents the comparison of the structures in relation to the rigidity index.

\begin{tabular}{|c|c|c|c|c|c|c|}
\hline TABELA 2. & & \multirow{2}{*}{\multicolumn{5}{|c|}{$\begin{array}{l}\text { COMPARAÇÃO DA CONSTANTE DE PROPORCIONALIDADE - } \mathbf{k}(\mathbf{N} / \mathrm{mm}) \text { ENTRE O } \\
\text { LIGAMENTO CRUZADO ANTERIOR (LCA), O ENXERTO DO LIGAMENTO PATELAR } \\
\text { (LP) E O SEMITE NDÍNEO E GRACIL (STG), SEGUNDO OS CICLOS (IDENTIFICADOS } \\
\text { EM SUBSCRITO) (?=0,05) } \\
\text { Comparison of the proportionality constant - } \mathrm{k}(\mathrm{N} / \mathrm{mm}) \text { for the anterior cruciate } \\
\text { ligament (ACL), the patellar ligament (PL) graft, and the semitendinosus and gracilis } \\
\text { (STG) muscles, according to the cycles (subscripts) }(?=0.05)\end{array}$}} \\
\hline \multicolumn{2}{|l|}{ TABLE 2.} & & & & & \\
\hline \multicolumn{7}{|c|}{$\begin{array}{l}\text { CONSTANTE DE PROPORCIONALIDADE k (N/mm) } \\
\text { Proportionality Constant k (N/mm) }\end{array}$} \\
\hline \multicolumn{3}{|c|}{ Comparação } & & este estatísti & & Significância \\
\hline $\begin{array}{l}\operatorname{LCA}_{1-2-3} \\
\operatorname{LCA}_{1-2-3} \\
\operatorname{LP}_{1} \\
\operatorname{LCA}_{1-2-3} \\
\operatorname{LCA}_{1-2-3} \\
\operatorname{LP}_{2-3} \\
\operatorname{LCA}_{1-2-3} \\
\operatorname{LP}_{2-3} \\
\operatorname{LCA}_{1-2-3} \\
\operatorname{LCA}_{1-2-3}\end{array}$ & $\begin{array}{l}\mathbf{x} \\
\mathbf{x} \\
\mathbf{x} \\
\mathbf{x} \\
\mathbf{x} \\
\mathbf{x} \\
\mathbf{x} \\
\mathbf{x} \\
\mathbf{x} \\
\mathbf{x}\end{array}$ & $\begin{array}{l}\text { LP }_{1} \\
\text { STG }_{1} \\
\text { STG }_{1} \\
\text { LP }_{2-3} \\
\text { STG }_{2} \\
\text { STG }_{2} \\
\text { STG }_{3} \\
\text { STG }_{3} \\
\text { LP }_{2-3} \\
\text { STG }_{3}\end{array}$ & $\begin{array}{l}\text { Wilcoxon } \\
\text { tpareado } \\
\text { Wilcoxon } \\
\text { tpareado } \\
\text { tpareado } \\
\text { tpareado } \\
\text { tpareado } \\
\text { tpareado } \\
\text { tpareado } \\
\text { tpareado }\end{array}$ & $\begin{array}{l}T=-188 \\
t=1,48 \\
T=-186 \\
t=3,49 \\
t=11,57 \\
t=9,59 \\
t=10,70 \\
t=8,65 \\
t=3,4646 \\
t=10,6143\end{array}$ & $\begin{array}{l}p=0,0005 \\
p=0,1545 \\
p=0,0006 \\
p=0,0024 \\
p<0,0001 \\
p<0,0001 \\
p<0,0001 \\
p<0,0001 \\
p=0,0026 \\
p<0,0001\end{array}$ & $\begin{array}{c}* \\
\text { n.s. } \\
* \\
* \\
* \\
* \\
* \\
* \\
* \\
*\end{array}$ \\
\hline
\end{tabular}




\section{DISCUSSÃO}

A freqüência crescente da lesão do $\operatorname{LCA}^{(4,16)}$ e a ocorrência de resultados insatisfatórios da reparação desse ${ }^{(19)}$, tem incentivado a investigação para o aprimoramento das técnicas de reconstrução para este ligamento.

A técnica de reconstrução do LCA teve como precursor J ONES ${ }^{(14)}$, que utiliza a porção central do LP, utilizada, desde então, por muitos cirurgiões ortopédicos. Esse substituto tem sido utilizado por apresentar resistência suficiente para suportar a carga a que o joelho é submetido e por possuir maior rigidez do que o LCA (18). Por outro lado, a utilização desse enxerto pode apresentar complicações em sua área doadora.

Atualmente, outras opções de enxerto são utilizadas como substituto do LCA, entre elas, o tendão do músculo semitendíneo, que pode ser utilizado de forma dupla ${ }^{(9)}$, de forma tripla ${ }^{(5)}$ ou mesmo associado ao tendão do músculo grácil, adquirindo uma forma quádrupla ${ }^{(15)}$. Esses tendões não são utilizados isoladamente de forma simples por apresentarem resistência inferior à do LCA ${ }^{(18)}$

Os insucessos da reconstrução ligamentar do LCA são multifatoriais. Um dos fatores, é o comportamento viscoelástico dos tecidos biológicos, fazendo com que as características fisiológicas e mecânicas de um tendão seja diferente do de um ligamento ${ }^{(22) .}$

Pretendeu-se, experimentalmente, estudar o comportamento da rigidez do LCA e dos enxertos utilizados para sua reconstrução através de ensaios mecânicos, na tentativa de melhorar suas propriedades estruturais e, talvez, utilizá-las na prática clínica, melhorando assim, os resultados finais da reconstrução do LCA.

A retirada das peças anatômicas obedecem critérios para que os corpos de prova pudessem ter boa fixação às garras. A dissecção realizada foi sempre cuidadosa para que essas estruturas não sofressem danos. Mesmo assim, desprezaramse as peças anatômicas no momento da dissecção quando o comprimento do tendão do músculo semitendíneo estava abaixo dos valores preconizados neste estudo.

O preparo das peças anatômicas para a realização dos ensaios mecânicos foi padronizado para o LCA, LP e para os tendões dos músculos STG.

Por serem estruturas viscoelásticas, os ligamentos e tendões apresentam diferente comportamento em função da velocidade em que são testados. ${ }^{(20)}$ Portanto, é grande importância a

\section{DISCUSSION}

The increasing frequency of $A C L$ lesions ${ }^{4,16}$ and the occasional unsatisfactory results to repair them have encouraged studies to improve the technique for reconstructing this ligament.

The $A C L$ reconstruction technique has its precursor, J ONES ${ }^{14}$, who uses the PL central part; this technique is employed by a number of orthopedic surgeons. This substitute presents sufficient resistance to support the load the knee is submitted to and because it presents more rigidity than the $A C L^{18}$. On the other hand, the utilization of this graft can cause complications in the donor area.

Today, other options are used as substitutes for the ACL, as the semitendinosus muscle tendon which can be used in double ${ }^{9}$ or triple $\mathrm{e}^{5}$ form or even associated to the gracilis muscle tendon, showing a quadruple form ${ }^{15}$. These tendons are not used alone in simple form since their resistance is inferior to the ACL's. ${ }^{18}$

Failure in reconstructing $A C L$ has many factors. One of them is the biological tissue viscoelastic behavior in that the physiological and mechanical characteristics of a tendon are different from those of a ligament ${ }^{22}$.

Our intention was to experimentally study the $A C L$ rigidity behavior and that of grafts used in its reconstruction through mechanical tests, attempting to refine its structural properties and maybe using them in clinical practice, improving the final results of the $A C L$ reconstruction.

The withd rawal of anatomical parts obey to criteria aiming that the samples show good fixation to the clamps. Dissection must be careful not to damage the structures. Even though, anatomical parts are discarded during dissection when the length of the semitendinosus muscle tendon is below the values preconized in this study.

The preparation of the anatomical parts to carry outmechanical tests was standardized for $A C L, P L$ and the STG muscles tendons.

As visc oelastic structures, the ligaments and tendons behave differently according to speed..$^{20}$ Accordingly, the mechanical test speed is of major importance so no interference occurs in the final results. On the other hand, different speeds interfere more significantly in the maximum load, but this was not the aim of this study. ${ }^{17}$ 
velocidade dos testes mecânicos para que essa não interfira nos resultados finais. Por outro lado, afirmam que a variação da velocidade interfere de forma mais significativa na carga máxima, propriedade esta que não foi motivo de nesse estudo. ${ }^{(17)}$

A velocidade adotada, $20 \mathrm{~mm} / \mathrm{min}$, é a recomendada para este tipo de material, e é a mesma adotada por HERNANDEZ ${ }^{(12)}$, considerada velocidade média de ensaio mecânico. Utilizou-se uma célula de carga $\mathrm{CCl}$ de 100 kgf de maneira a obter maior precisão nas leituras (precisão acima de 5 kgf e menor divisão de 5 gf).

A carga de pré-tensão equivalente a 147,15 N (15 kgf) foi adotada observando os trabalhos in vivo (2 e 10), através da colocação de um transdutor de deformação no LCA íntegro, nos quais utilizam essa mesma carga para realização do estudo. Uma vez que esse valor não deletéria o LCA íntegro, padronizou-se essa carga suficiente para produzir os efeitos desejados sem provocar uma sobrecarga no enxerto ou colocar em risco a fixação. Importante salientar que esse valor se encontra muito abaixo da carga máxima dos enxertos estudados. Portanto estudou-se essas estruturas dentro da faixa mecânica considerada elástica.

O desenho do estudo previu a utilização de um controle e a comparação entre as estruturas relacionadas (LCA e enxertos produzidos com o LP e STG do mesmo joelho) de maneira a obter o máximo rendimento dos testes estatísticos, ou seja, utilizar o menor número de joelhos e garantir o maior poder-eficiência possível das análises.

Nos ensaios mecânicos das estruturas (tração) procurou-se uma deformação lenta e continua até alcançar-se uma resistência nominal pré-programada de 147,15 N (15 Kgf), momento, a partir do qual estabeleceu-se um período de monitoração da redução da força de reação com duração de 900 s (15 min).

O comportamento viscoelástico é complexo e superpõem-se sempre ao comportamento elástico convencional, necessitando portanto de análises individuais de cada parâmetro.

Essas análises são, normalmente, realizadas através do diagrama carga (ou tensão) x deformação como o realizado neste estudo, gerados a partir de ensaios quase-estáticos. ${ }^{(17)}$

Dentre esses parâmetros destacam-se a obtenção das curvas de histerese e sua variação em função da velocidade de aplicação de cargas (resistência, elasticidade e rigidez), do escoamento e da deformação residual a partir de diagramas força $x$ deformação e do relaxamento à tensão e da recuperação pelos diagramas força $x$ tempo.
The $20 \mathrm{~mm} / \mathrm{min}$ speed is recommended for this material, and is also adopted by HERNANDEZ ${ }^{12}$; it is considered the average speed for mechanical tests. A $100 \mathrm{kgfCCl}$ load cell was used to produce more accurate readings (precision above $5 \mathrm{kgf}$ and smallest division $5 \mathrm{gf}$ ).

A pre-tension load equivalent to $147.15 \mathrm{~N}$ (15 kgf) was adopted according to in vivo studies ${ }^{2,10}$ placing a deformation transducer in the intact $A C L$. This load is harmless to the intact $A C L$ so it was considered sufficient to produce the desired effects without provoking an onverload on the graft or involving risks to the fixation. It is important to emphasize that this amount is quite below the maximum load for the studied grafts. Accordingly, these structures were studied within the elastic mechanical range.

The design of the study antic ipated the utilization of a control and the comparison of related structures ( $A C L$ and grafts produced with PL and STG in the same knee) as to obtain maximum profit from the statistical tests, that is, to use as few knees as possible and guarantee as much power-efficiency as possible from the analysis.

In the mechanical test of the structures (traction) a slow and continuous deformation was produced until a pre-programmed nominal resistance of $147.15 \mathrm{~N}(15 \mathrm{Kgf})$ is reached, momentum, then establishing a $900 \mathrm{~s}$ ( $15 \mathrm{~min}$ ) duration monitoring period of reduction of the reaction force.

The viscoelastic behavior is complexand always overlaps the conventional elastic behavior so each parameter must be individually analyzed.

Usually, these analysis are carried out using the load (or tension) $x$ deformation diagram generated from quasi-static tests $^{17}$ as in this study.

Among these parameters the obtention of hysteresis curves is pointed out as well as the variation as a function of speed of load application (resistance, elasticity and rigidity), flowing and residual deformation from force $x$ deformation diagrams, and tension relaxation and recuperation through the force $x$ time diagrams.

The parameter rigidity was analyzed since itcould significantly interfere with the grafts whose mechanical function is predominantly to stabilize the knee articulation. 
O ptou-se por analisar o parâmetro rigidez que poderia interferir de maneira significativa nos enxertos cuja função mecânica é predominantemente o de estabilizar a articulação do joelho.

Estudaram-se as variações em 3 ciclos dos parâmetros de relaxamento à tensão (variação absoluta e relativa da força após 900s (15 min) de relaxamento à tensão e da rigidez do LCA (controle) e dos enxertos para sua reconstrução preparados com o LP e com os tendões duplos dos músculos STG.

A variação da rigidez, avaliada pela constante de proporcionalidade de $k$, foi mostrada na Tabela 1.

A rigidez do LCA manteve-se constante entre os ciclos, em torno de $82 \mathrm{~N} / \mathrm{mm}$. Os enxertos apresentaram elevação da rigidez com a ciclagem. A rigidez do enxerto com LP estabilizou-se entre o 1 을응 ciclos. A literatura consultada é controvérsia para esse estudo. YOSHIYA ${ }^{(24)}$ demonstra que os enxertos tensionados á baixa tensão , apresentam uma maior rigidez quando comparados com tensões mais elevadas. HAMNER ${ }^{(11)}$ relata que quatro bandas do STG são mais ńgidos quando comparados ao LP. Por outro lado, transferindo para a parte clínica , YASUDA ${ }^{(23)}$, através de estudo com tendões dos músculos STG, aplica diferentes tensões no enxerto e encontra uma estabilidade clínica maior para àqueles que receberam maior tensão no enxerto. VAN KAMPEM(21), não encontra diferenças significativa da avaliação clínica em seu estudo com relação à rigidez, quando são aplicadas diferentes tensões nos enxertos.

Nas comparações entre as estruturas, Tabela 2, observou-se que a rigidez do LP no 1 -c ciclo foi inferior às apresentadas pelo LCA, constantes no 1ㅇ, 2ㅇ e 3ㅇc ciclos, porém superou às do LCA a partir do 2 - ciclo. A rigidez da STG no 1 o ciclo foi semelhante a do LCA e superior nas demais. Os tendões do STG apresentou rigidez superior à do LP nos ciclos correspondentes.

De maneira geral, constataram-se diferenças significativas entre - LCA e as estruturas utilizadas comumente para sua reconstrução, o LP e os tendões dos músculos STG, quanto a rigidez. Verificouse, também, que os dois tipos de enxerto apresentaram características distintas entre si.

Constatou-se, também, que a ciclagem aumenta a rigidez dos enxertos em relação ao LCA, onde esta variação é menor, não havendo diferença estatística entre $02^{\circ}$ e o $3^{\circ}$ teste do LCA

Devem, também, ser investigadas as demais características viscoelásticas dos tecidos utilizados para enxerto do LCA, como o relaxamento à tensão e o escoamento (arrastamento) de maneira a determinar os fatores de interferência, desenvolver as técnicas cirúrgicas e de reabilitação acelerada e para melhor seleção das estruturas utilizadas na preparação dos enxertos. ${ }^{(6,13)}$
Variations of the 3 cycles were studied for the relaxation to tension parameters (absolute and relative variation of force after 900s (15 min), of relaxation to tension and rigidity of the $A C L$ (control), and of the grafts for reconstruction prepared with $\mathrm{PL}$ and double tendons of the STG muscles.

The range of rigidity, determined by the proportionality constant $k$, is presented in Table 1.

The ACL rigidity was constant during the cycles, about $82 \mathrm{~N} /$ $\mathrm{mm}$. The grafts presented intensification of rigidity with cycling. The rigidity of the graft with $\mathrm{PL}$ stabilized between the $1^{\text {st }}$ and $3^{\text {rd }}$ cycles. The literature is controverse in this aspect. YOSHIYA24 reports that grafts tractioned with low tension presentmore rigidity when compared to higher tensions. HAMNER ${ }^{11}$ reports that four STG bands are stiffer when compared to the PL. On the other hand, under a clinical point of view, YASUDA ${ }^{23}$ studying the STG muscles tendons, applies different tensions to the grafts and finds a better clinical stability for those more tensioned. VAN KAMPEM ${ }^{21}$ found non-significant differences concerning rigidity in the clinical evaluation of his study, when different tensions are applied on the grafts.

Table 2 compares the structures and shows that the PL rigidity in the $1^{\text {st }}$ cycle was inferior to those for the $A C L$, constant in the $1^{\text {st }}, 2^{\text {nd }}$ and $3^{\text {rd }}$ cycles, but superior to the $A C L$ from the $2^{\text {nd }}$ cycle on. Rigidity of STG in the $1^{\text {st }}$ cycle was similar to the $A C L$ and superior in the other cases. The STG tendons presented rigidity superior to the $\mathrm{PL}$ in the correspondent cycles.

In general, significant differences were found among the $A C L$ and the structures commonly used for its reconstruction, the $\mathrm{PL}$ and the STG muscles tendons, as far as rigidity is concerned. It was also found that the two different grafts presented different characteristics.

Cycling increased the grafts rigidity concerning the $A C L$ when this variation was lower, and no statistical difference was found between the $2^{\text {nd }}$ and $3^{\text {rd }}$ tests of the ACL.

Other viscoelastic characteristics of tissues used for the $A C L$ graft must be investigated, as tension relaxation and flowing (dragging) so as to determine the interference factors, develop surgical techniques and accelerate rehabilitation as well as to refine the selection of structures to be used used in graft preparation. 6,13

The main objective is to reduce risks, both due to early mistakes and late instabilities, reducing consequently the overall cost of the treatment; this seems possible partly due to the realization of adequate pre-tensioning. 
O principal objetivo no entanto continua sendo o de reduzir os riscos para os pacientes, tanto o de falhas precoces quanto o de instabilidades tardias reduzindo consequentemente os custos globais de tratamento, o que parece ser possível, em parte, pela realização de um pré-tensionamento adequado.

Na prática clínica é certeza da necessidade de realizar o prétensionamento dos enxertos utilizados no momento da fixação deste, devido o seu comportamento viscoelástico, sendo este tecido específico. É certeza, também, da necessidade de se determinar um tempo necessário para que ocorra o escoamento da estrutura, e a fixação imediata do tecido pré-tensionado, pois o mesmo é perdido em grande parte nos primeiros minutos pós-tensionamento.

Acredita-se que seria impossível determinar um valor numérico que quantifique a carga que deve ser aplicada, pois certamente ocorrem variações de joelho para joelho e de indivíduo para indivíduo. 0 importante é não aplicar a uma tensão excessiva e menos ainda aplicar uma tensão insuficiente, pois em ambos os casos poderá comprometer os resultados finais da reconstrução.
In clinical practice it is undoubtedly necessary to carry out pre-tensioning of the graft when it is fixed, due to its viscoelastic behavior and because it is a specific tissue. It is certainly necessary to determine a time interval in order that flowing occurs, and immediate fixation of the pre-tensioned tissue, since great part of it is lost during the first post-tensioning minutes.

One believes that it would be impossible to determine a numerical value to quantify the load to be applied, since certainly variations occurbetween knees and from one individual to another. It is important not to apply excessive or insufficient tension, or the final results of the reconstruction can be compromised.

\section{CONCLUSÃO}

0 autor concluiu, em relação ao LCA e aos enxertos utilizados para sua reconstrução com o LP e com os tendões dos músculos do STG que: Os ciclos sucessivos de relaxamento à tensão determinam um aumento da rigidez dos enxertos analisados.

\section{CONCLUSION}

The conclusion was that, in relation to the $A C L$ and the grafts used to reconstruct it with the PL and STG muscles tendons: The successive cycles from relaxation to tension determine an increase in the rigidity of the analyzed grafts.

\section{REFERÊNCIAS}

1. AMATUZZI, M. M.; GOUVEIA, J. L. F.; PADILHA, O. S. Tratamento cinúrgico das instabilidades anteriores crônicas do joelho. Rev. Bras. O rtop., v. 21, p. 37-43, 1986.

2. BEYNNON, B.; HOWE, J . G.; POPE, M H.; J OHNSON, R. J .; FLEMING, B. C. The measurement of anterior cruciate ligament strain in vivo. Int. Orthop., v. 16, p. 1-12, 1992.

3. BURKS, R. T.; LELAND, R. Determination of graft tension before fixation in anterior cruciate ligament reconstruction. Arthroscopy, v. 4 , p. $260-66,1988$.

4. BURNETT, Q. M.; FOWLER, P. J . Reconstruction of the anterior cruciate ligament: historical overview. O rthop. Clin. North Am., V. 16, P. 143-57, 1985.
5. CAMANHO, G.L.; OLIVI, R. O uso do tendão do músculo semitendíneo fixo com "Endobutton" no tratamento das instabilidades anteriores do joelho. Rev. Bras. Ortop., v. 31, p. 369-72, 1996.

6. CHIMICH, D. SHRIVE, N.; FRANK, C.; MARCHUK, L. AND BRAY, R. Water content alters viscoelastic behaviour of the nomal adolescent rabbit medial collateral ligament. J. Biomech., v. 25, p. 831-7, 1992

7. COLLINS, J. J.; M'CONNOR, J. J. Muscle ligament interactions at the knee during walking. Proc. Inst. Mech. Eng.[H], v. 205, p. 11-8, 1991.

8. DEJ OUR, H; WALCH, G; NEYRET, P.; ADELEINE, P. Résultats des laxités chroniques antérieures opérées. A propos de 251 cas revus avec un recul minimum de 3 ans. Revue de cirurgie Orthopédique, v. 74, p. 622-36, 1988. 
9. ELLERA GOMES, J . L.; MARCZYK, L. R. Anterior cruciate ligament reconstruction with a loop or double thickness of semiten tendon. Am. J. S ports Med., v. 12, p. 199-203, 1984.

10. FLEMING, B. C.; BEYNNON, B. D.; NICHOLS, C. E.; J OHNSON, R. J .; POPE, M. H. An in vivo comparison of anterior tibial translation and strain in the anteromedial band of the anterior cruciate ligament. J. Biomech., v.26, p. 51-8, 1993.

11. HAMMER, D. L.; BROWN, C. H. J r.; STEINER, M.E.; HECKER, A.; HAYES, WC. Hamstring tendon grafts for reconstruction of the anterior cruciate ligament: biomechanical evalution of the use of multiple strands and tensioning techniques. J. B one J oint Surg.[Am], v. 81, p. 549-57, 1999.

12. HERNANDEZ, A. J. Correlação das propriedades biomecanicas dos ligamentos do joelho com seus parâmetros antropométricos. São Paulo, 1994. 162 p. Tese (Doutorado), Faculdade de Medicina da Universidade de São Paulo.

13. HOWARD, M. E.; CAWLEY, P. W.; LOSSE, G. M.; J OHNSTON, R. B. Bone-patellar tendon-bone grafts for anterior cruciate ligament reconstruction: the effects of graft pretensioning. Arthroscopy, $v$. 12, p. 287-92, 1996.

14. J ONES, K. G. Reconstruction of the anterior cruciate ligament. J . Bone J oint. Surg.[Am], v. 45, p. 925-31, 1963.

15. LIPSCOMB, A. B.; J OHNSTON, R. K.; SNYDER, R. B.; WARBURTON, M. J .; GILBERT, P. Evaluation of Hamstring Strenth Following use of Semitendinosus and Gracilis Tendons to Reconstruct the Anterior Cruciate Ligament. Am. J . S ports Med., V. 10, P. 340-2, 1982.

16. NOYES, F. R.; BASSET, R. W.; GROOD, E. S.; BUTLER, D. L. Arthroscopy in acute traumatic hemarthrosis of the knee. Incidence of anterior cruciate tears and other injuries. J. B one J oint Surg.[Am ], V. 62, P. 687-95, 1980.
17. NOYES, F. R.; BUTLER, D. L.; GROOD, E. S.; ZERNICKE, R. F; HEFZY, M. S. Biomechanical analysis of human ligament grafts used in knee-ligament repairs and reconstructions. J . B one J oint S urg.[ Am], v. 66, p. 344-52, 1984.

18. NOYES, F. R.; KELLER, C. S.; GROOD , E. S.; BUTLER, D. L. Advances in the understanding of knee ligament injury, repair and rehabilitation. Med. Sci. Sports Exerc., v. 16, p. 427-43, 1984.

19. ODENSTEN, M.; LYSHOLM,J .; GILQUIST,J . Suture of fresh ruptures of the anterior cruciate ligament. A 5 year follow-up. Acta $\mathbf{0}$ rthop. Scand, v. 55, p. 270-2, 1984.

20. TAYLOR, D. C.; DALTON, J. D.; SEABER, A. V.; GARRETT, W. E. Viscoelastic properties of muscle-tendon units. Am. J. Sports Med., v. 18, p. 300-9, 1990.

21. VAN KAMPEN, A.; WYMENGA, A. B.; VAN DER HEIDE, H. J .; BAKENS , H.J. The effect of different graft tensioning in anterior cruciate ligament reconstruction: a prospective randomized study. Arthroscopy, v. 14, p. 845-50, 1998.

22. WOO, S. L-Y.; LIVESAY, G. A.; RUNCO, T.J .; YOXNG, E. P. Structure and function of tendons and ligaments. Basic O rthopaedic Biomechanic s, 2 $2^{\text {nd }}$ ed. capítulo 6, p. 209-251, 1997.

23. YASUDA, K.; TSUJ INO, J.; TANABE, Y.; KANEDA, K. Effects of initial graft tension on clinical outcome after anterior cruciate ligament reconstruction. Autogenous doubled hamstring tendons connected in series with polyester tapes. Am. J . S ports Med., v. 25, p. 99106, 1997.

24. YOSHIYA, S.; ANDRISH, J. T.; MANLEY, M. T.; BAUER, T. W. Graft tension in anterior cruciate ligament reconstruction. An in vivo study in dogs. Am. J. S ports Med., v. 15, p. 464-70, 1987. 